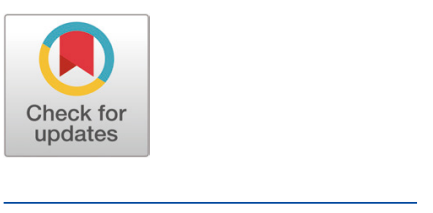

Received: Oct 22, 2019

Revised: Feb 28, 2020

Accepted: Feb 28, 2020

\#These authors contributed equally to this work.

*Corresponding author

Minho Song

Division of Animal and Dairy Science,

Chungnam National University,

Daejeon 34134, Korea.

Tel: +82-42-821-5776

E-mail: mhsong@cnu.ac.kr

Hyeun Bum Kim

Department of Animal Resources

Science, Dankook University,

Cheonan 31116, Korea.

Tel: +82-41-550-3653

E-mail: hbkim@dankook.ac.kr

Copyright $\odot 2020$ Korean Society of Animal Sciences and Technology.

This is an Open Access article distributed under the terms of the Creative Commons Attribution Non-Commercial License (http:// creativecommons.org/licenses/by$\mathrm{nc} / 4.0 /$ ) which permits unrestricted non-commercial use, distribution, and reproduction in any medium, provided the original work is properly cited.

ORCID

Jeong Jae Lee

https://orcid.org/0000-0002-3455-0102 Joowon Kang

https://orcid.org/0000-0001-7340-1479

Sangwoo Park

https://orcid.org/0000-0003-2288-1374

\section{Effects of dietary protease on immune responses of weaned pigs}

\author{
Jeong Jae Lee ${ }^{1 \#}$, Joowon Kang ${ }^{1 \#}$, Sangwoo Park ${ }^{1 \#}$, Jin Ho Cho ${ }^{2 \#}$, Sejong Oh ${ }^{3}$ \\ Dong-Jun Park ${ }^{4}$, Rider Perez-Maldonado ${ }^{5}$, Jee-Yeon Cho ${ }^{6}$, Il-Hun Park ${ }^{6}$, \\ Hyeun Bum Kim ${ }^{7 *}$ and Minho Song ${ }^{1 *}$ \\ ${ }^{1}$ Division of Animal and Dairy Science, Chungnam National University, Daejeon 34134, Korea \\ ${ }^{2}$ Division of Food and Animal Science, Chungbuk National University, Cheongju 28644, Korea \\ ${ }^{3}$ Department of Animal Science, Chonnam National University, Gwangju 61186, Korea \\ ${ }^{4}$ Korea Food Research Institute, Wanju 55365, Korea \\ ${ }^{5}$ DSM Nutritional Products Asia Pacific, Mapletree Business City 117440, Singapore \\ ${ }^{6}$ DSM Nutrition Korea Ltd., Seoul 06675, Korea \\ ${ }^{7}$ Department of Animal Resources Science, Dankook University, Cheonan 31116, Korea
}

\section{Abstract}

This experiment was conducted to investigate effects of dietary protease on immune responses of weaned pigs. Weaned pigs ( $n=75 ; 7.06 \pm 0.18 \mathrm{~kg} \mathrm{BW} ; 28 \mathrm{~d}$ old) were randomly assigned to 3 treatments ( 5 pigs/pen; 5 pens/treatment). Dietary treatments were positive control, a diet with required protein level (PC), negative control, a diet with lower protein level than $\mathrm{PC}(\mathrm{NC})$, and $\mathrm{NC}+0.02 \%$ dietary protease (PRO). The dietary protease used in this experiment was a commercial product containing 75,000 protease units/g derived from Nocardiopsis prasina produced in Bacillus licheniformis. The dietary treatments did not contain any ingredients or additives that may provide antibacterial or physiological effects. Pigs were fed respective dietary treatments for 6 weeks. Blood was collected from randomly selected 2 pigs in each pen on $d 1,3,7$, and 14 after weaning. Measurements were number of white blood cells (WBC), tumor necrosis factor- $\alpha$ (TNF- $\alpha$ ), transforming growth factor- $\beta 1$ (TGF- $\beta 1$ ), and C-reactive protein (CRP). Pigs fed PRO had lower WBC on d 7 (14.84 vs $20.42 \times 10^{3}$ ) $\mu \mathrm{L} ; p<0.05)$ and TNF- $\alpha$ on $\mathrm{d} 7(618 \mathrm{vs} 889 \mathrm{pg} / \mathrm{mL} ; p=0.085)$ and $14(437 \mathrm{vs} 576 \mathrm{pg} / \mathrm{mL} ; p$ $=0.069$ ) than those fed NC, but there were no differences on WBC and TNF- $\alpha$ between PC and PRO. Pigs fed PRO had lower TGF- $\beta 1$ on d 3 (630 vs. 1,588 and $1,396 \mathrm{pg} / \mathrm{mL} ; p<0.05$ ) than those fed PC and NC. However, no differences were found on CRP among dietary treatments. In conclusion, addition of dietary protease reduced inflammatory immune responses of weaned pigs.

Keywords: Dietary protease, Immune response, Weaned pigs

\section{INTRODUCTION}

Weaner pig diets mainly consist of corn and soybean meal (SBM) and contain approximately $20 \%$ of crude protein $(\mathrm{CP})$ [1], but the $\mathrm{CP}$ digestibility or availability in weaned pigs ranges is from $60 \%$ to $80 \%$ due to their immature digestive system [2]. Undigested protein can be a source for pathogenic bacteria in the gut to ferment consequently and can contribute to causing post-weaning diarrhea and 
Jin Ho Cho

https://orcid.org/0000-0001-7151-0778

Sejong Oh

https://orcid.org/0000-0002-5870-3038

Dong-Jun Park

https://orcid.org/0000-0001-9452-9391

Rider Perez-Maldonado

https://orcid.org/0000-0001-7695-5258

Jee-Yeon Cho

https://orcid.org/0000-0002-7067-1841

II-Hun Park

https://orcid.org/0000-0003-0851-4180

Hyeun Bum Kim

https://orcid.org/0000-0003-1366-6090

Minho Song

https://orcid.org/0000-0002-4515-5212

Competing interests

No potential conflict of interest relevant to

this article was reported.

Funding sources

This study was financially supported by

the research fund of Chungnam National

University in 2019

Acknowledgements

The financial contribution of DSM Nutritional

Products, Singapore Office is highly appreciated.

Availability of data and material

Upon reasonable request, the datasets

of this study can be available from the

corresponding author.

\section{Authors' contributions}

Conceptualization: Song M.

Data curation: Cho JH, Kim HB.

Formal analysis: Perez-Maldonado R, Cho JY.

Methodology: Park IH.

Software: Oh S, Park DJ.

Validation:Lee JJ, Kang J.

Investigation: Park S, Cho JH, Kim HB.

Writing - original draft: Lee JJ, Kang J, Park S, Song $\mathrm{M}$.

Writing - review \& editing: Park S, Cho JH,

Kim HB, Song M.

Ethics approval and consent to participate The protocol for this experiment was reviewed and approved by the Institutional Animal Care and Use Committee of Chungnam National University, Daejeon, Korea (approval code: CNU-00611). death of pigs [3-6]. Furthermore, undigested protein not used by pigs can be excreted to cause environmental pollution, such as nitrogen emission $[7,8]$. Due to these issues, the swine industry has been looking for the solutions to improve the availability of protein in pig diets.

Addition of dietary protease to weaner pig diets may be a solution to improve the protein availability of pigs after weaning [9-11]. Dietary protease is an enzyme that hydrolyzes high molecular weight polypeptides into lower molecular weight oligopeptides for further digestion by endogenous proteases [12]. Dietary protease properties include to break down protein-bound complexes with anti-nutritional factors and are typically used in swine and poultry diets as a mono-component or multi-enzyme products [13-15]. Several studies showed addition of dietary multi-enzymes with the protease in pig diets improved digestibility of protein and other nutrients as well as growth performance of pigs with different stages of age [15-17]. In addition, several recent studies reported dietary protease application as a mono-component in pig diets had positive effects on growth rate, protein digestibility, and gut health of pigs [15,18]. However, there was no information about immune responses of weaned pigs fed diets with dietary mono-component protease. Therefore, the purpose of this study was to verify effects of dietary protease in a diet based on corn and SBM on immune responses of weaned pigs.

\section{MATERIALS AND METHODS}

The protocol for this experiment was reviewed and approved by the Institutional Animal Care and Use Committee of Chungnam National University, Daejeon, Korea. This experiment was conducted at the Animal Research Center of Chungnam National University.

\section{Experimental design, animals, and diets}

Weaned pigs [Duroc $\times$ (Landrace $\times$ Yorkshire); $\mathrm{n}=75 ; 7.06 \mathrm{~kg}$ of average body weight $(\mathrm{BW})]$ were randomly allotted to 3 diets (3 barrows and 2 gilts per pen; 5 replicates per diet) in a randomized complete block design (block = BW and sex). The diets were a basal diet with corn and SBM basis to meet or exceed the requirement of crude protein [positive control diet (PC)],2) a lower protein diet than $\mathrm{PC}$ [negative control diet (NC)], and 3) $\mathrm{NC}+0.02 \%$ dietary protease (PRO). The dietary protease was a commercial product (Ronozyme ${ }^{\circledR}$ ProAct, DSM nutrition products, Kaiseraugst, Switzerland) containing 75,000 protease units/g derived from Nocardiopsis prasina produced in $\mathrm{Ba}$ cillus licheniformis. The basal diet did not include any feed ingredients that may have any antibacterial or physiological effects, such as animal plasma, antibiotics, or zinc oxide (Table 1). All pigs were housed in an environmentally controlled room with a slatted plastic floor and allowed ad libitum access to diets and water for 6 weeks.

\section{Sample collection and immune measurements}

Blood samples from 2 weaned pigs (1 barrow and 1 gilt) in each pen were collected from the jugular vein of each pig with and without ethylenediaminetetraacetic acid (EDTA) tubes to yield whole blood and serum, respectively, on d 1,3,7, and 14 after weaning. The blood for serum was held to clot at room temperature for $2 \mathrm{~h}$, kept at $4^{\circ} \mathrm{C}$ overnight, and then centrifuged for $15 \mathrm{~min}$ at $3,000 \times$ $\mathrm{g}$ at room temperature. The number of white blood cells $(\mathrm{WBC})$ were analyzed using a multi-parameter, automated hematology analyzer calibrated for porcine blood (scil Vet abc hematology analyzer, scil animal care company, F-67120 Altorf, France). Inflammatory cytokines and C-reactive protein (CRP) were measured using porcine ELISA kits following the manufacturer's procedures [tumor necrosis factor- $\alpha$ (TNF- $\alpha$; Genorise Scientific, Berwyn, PA, USA); transforming growth factor- $\beta 1$ (TGF- $\beta$ 1; Genorise Scientific, Berwyn, PA, USA); CRP (Genorise Scientific, Berwyn, 
Table 1. Composition of basal diet for weaned pigs (as-fed basis)

\begin{tabular}{|c|c|c|}
\hline Items & PC & NC \\
\hline \multicolumn{3}{|l|}{ Ingredients (\%) } \\
\hline Corn & 56.09 & 58.09 \\
\hline Soybean meal (44\%) & 26.00 & 24.00 \\
\hline Soy protein concentrate & 12.00 & 12.00 \\
\hline Soybean oil & 3.00 & 3.00 \\
\hline Limestone & 1.30 & 1.30 \\
\hline Monocalcium phosphate & 1.20 & 1.20 \\
\hline Vitamin-mineral premix ${ }^{11}$ & 0.04 & 0.04 \\
\hline L-Lysine-HCl & 0.24 & 0.24 \\
\hline DL-Methionine & 0.09 & 0.09 \\
\hline L-Threonine & 0.04 & 0.04 \\
\hline Total & 100.00 & 100.00 \\
\hline \multicolumn{3}{|c|}{ Calculated energy and nutrient contents } \\
\hline Metabolizable energy (Mcal/kg) & 3.53 & 3.42 \\
\hline Crude protein (\%) & 24.49 & 22.51 \\
\hline Calcium (\%) & 0.81 & 0.73 \\
\hline Phosphorus (\%) & 0.69 & 0.63 \\
\hline Lysine (\%) & 1.54 & 1.41 \\
\hline \multicolumn{3}{|c|}{$\begin{array}{l}\text { 19The vitamin-mineral premix provided the following quantities of per kilogram of diet: vitamin } \mathrm{A}, 12,000 \mathrm{IU} \text {; vitamin } \mathrm{D}_{3}, 2,500 \mathrm{IU} \text {; } \\
\text { vitamin } \mathrm{E}, 30 \mathrm{IU} \text {; vitamin } \mathrm{K}_{3}, 3 \mathrm{mg} \text {; D-pantothenic acid, } 15 \mathrm{mg} \text {; nicotinic acid, } 40 \mathrm{mg} \text {; choline, } 400 \mathrm{mg} \text {; and vitamin } \mathrm{B}_{12}, 12 \mu \mathrm{\mu g} \text {; } \\
\mathrm{Fe}, 90 \mathrm{mg} \text { from iron sulfate; } \mathrm{Cu}, 8.8 \mathrm{mg} \text { from copper sulfate; } \mathrm{Zn}, 100 \mathrm{mg} \text { from zinc oxide; Mn, } 54 \mathrm{mg} \text { from manganese oxide; I, } \\
0.35 \mathrm{mg} \text { from potassium iodide; } \mathrm{Se}, 0.30 \mathrm{mg} \text { from sodium selenite. }\end{array}$} \\
\hline
\end{tabular}

PA, USA)]. All the cytokine measurements of serum samples were based on the report of Song et al. [19]. The intra-assay coefficients of variation for TNF- $\alpha$, TGF- $\beta 1$, and CRP were $6 \%, 6 \%$, and $6 \%$, respectively. The inter-assay coefficients of variation for TNF- $\alpha$, TGF- $\beta 1$, and CRP were $8 \%$, $11 \%$, and $9 \%$, respectively.

\section{Statistical analysis}

All data were analyzed using the PROC GLM procedure of SAS (SAS Inst., Cary, NC, USA) in a randomized complete block design. The experimental unit was the pen and blocks were BW and sex. The statistical model for the number of WBC, inflammatory cytokines (TNF- $\alpha$ and TGF- $\beta$ 1), and CRP included effects of diets as a fixed effect and BW and sex as covariates. In addition, pair-wise comparisons were performed among diets when a main effect of diet was found. Results are given as means \pm SEM. Statistical significance and tendency were considered at $p<0.05$ and 0.05 $\leq p<0.10$, respectively.

\section{RESULTS AND DISCUSSION}

Post-weaning period in pigs is the most stressful period due to nutritional, immunological, physiological, and environmental changes, and/or disease challenges [20]. Previous studies showed the stress factors can give a serious damage in gut health and impair immune functions of weaned pigs [21-24]. Further, the dysfunctional nutrient metabolism and impaired immune system caused by the post-weaning stressors can contribute to causing serious diarrhea and sudden mortality of weaned pigs $[8,25]$. As the present study showed, the concentrations of all inflammatory immune 
responses of weaned pigs were the highest maybe because of the post-weaning stress and decreased those gradually as pigs grew older. Under the conditions in present study, PRO decreased $(p<0.05)$ the number of WBC on $\mathrm{d} 7$ after weaning compared with $\mathrm{NC}$ (Fig. 1). The number of WBC can be used as an indicator for systemic inflammation and thus the higher number of WBC than normal condition indicates an ongoing systemic inflammation [26]. The PRO tended $(p<0.10)$ to decrease serum TNF- $\alpha$ on $\mathrm{d} 7$ and 14 compared with NC (Fig. 2). The TNF- $\alpha$ is one of the most important pro-inflammatory cytokines that stimulates systemic inflammation and acute phase reaction [21]. Interestingly, PRO decreased serum TGF- $\beta 1$ on $\mathrm{d} 3(p<0.05)$ and tended to decrease it on $\mathrm{d} 7$ and 14 ( $p<0.10$ ) compared with PC and/or NC (Fig. 3). The TGF- $\beta 1$ has functions both immune-suppressive and immune-enhancing activities [27]. As an anti-inflammatory cytokine, TGF- $\beta 1$ stimulates the proliferation and differentiation of T and B cells and deactivate monocyte/macrophage [28]. However, as a pro-inflammatory cytokine, TGF- $\beta 1$ in the presence

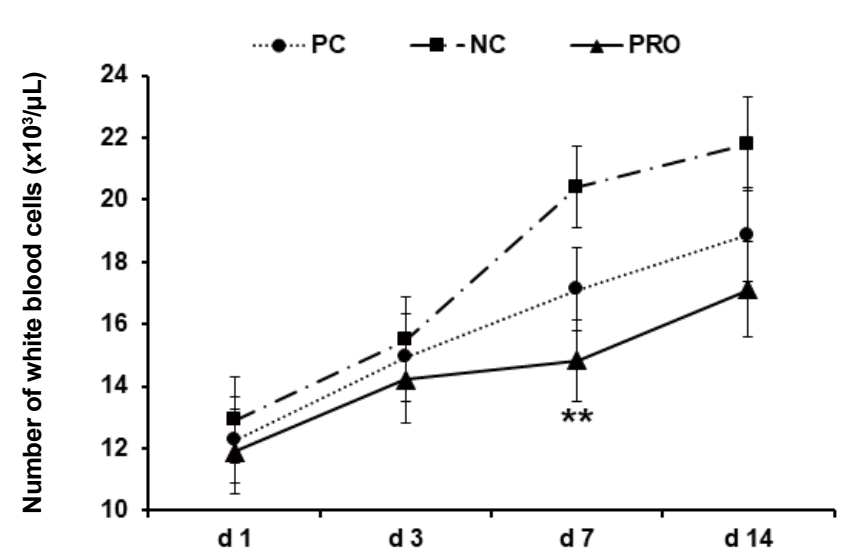

Fig. 1. Effect of dietary protease on number of white blood cells of weaned pigs. Each value is the mean of 5 replicates. ${ }^{*}$ Difference between PRO and NC $(p<0.05)$. PC, positive control; NC, negative control; $\mathrm{PRO}$, negative control $+0.02 \%$ dietary protease.

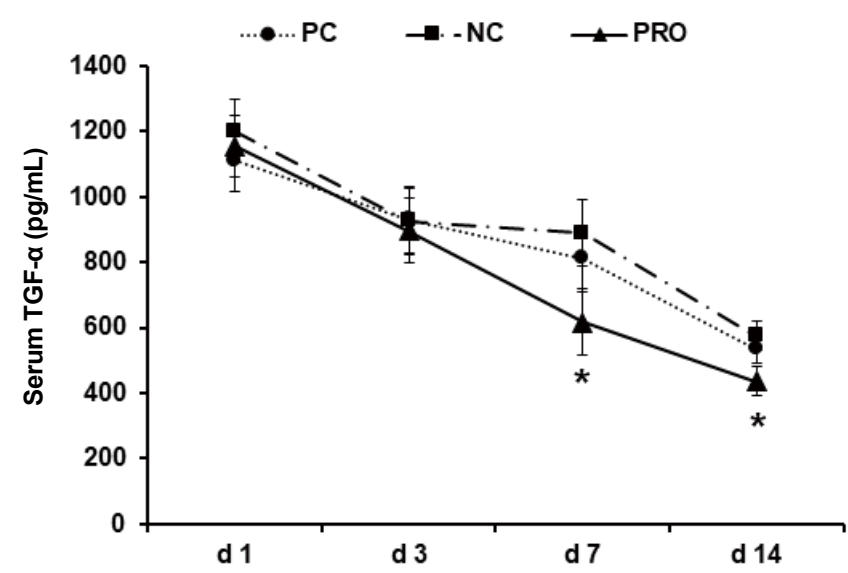

Fig. 2. Effect of dietary protease on serum TNF- $\alpha$ of weaned pigs. Each value is the mean of 5 replicates. *Difference between PRO and NC $(p$ $<0.10$ ). PC, positive control; NC, negative control; PRO, negative control + $0.02 \%$ dietary protease.

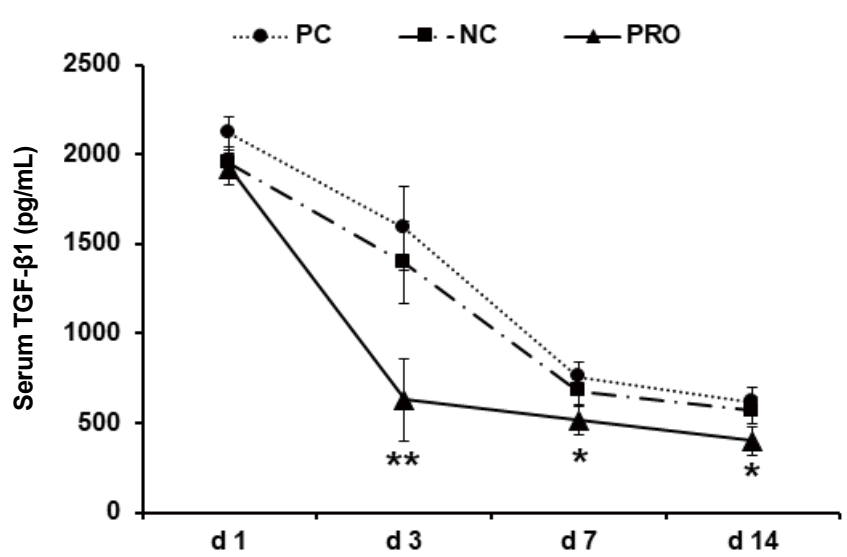

Fig. 3. Effect of dietary protease on serum TGF- $\beta 1$ of weaned pigs. Each value is the mean of 5 replicates. *Compared with PC and/or NC $(p<0.10)$. ${ }^{*}$ Difference between PRO and PC and/or NC $(p<0.05)$. PC, positive control; NC, negative control; PRO, negative control $+0.02 \%$ dietary protease.

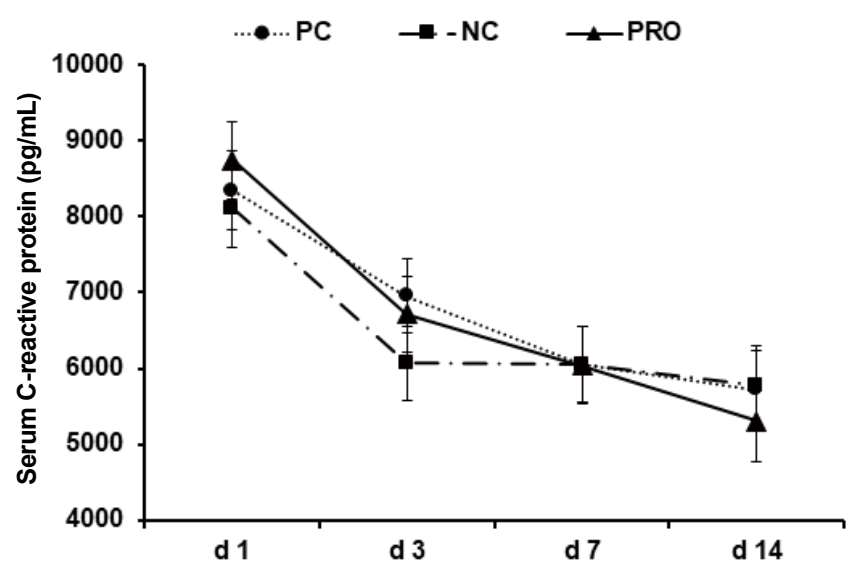

Fig. 4. Effect of dietary protease on serum C-reactive protein of weaned pigs. Each value is the mean of 5 replicates. $\mathrm{PC}$, positive control; $\mathrm{NC}$, negative control; $\mathrm{PRO}$, negative control $+0.02 \%$ dietary protease. 
of different cytokines can induce the differentiation of diverse $\mathrm{T}$ helper cells, which promote further tissue inflammation [29]. The concentration of serum CRP of all dietary treatments was getting decreased from d 1 to 14 after weaning (Fig. 4), but no protease effects were found. The CRP can be used as an inflammatory response indicator and pro-inflammatory cytokine such as TNF- $\alpha$ are critical inducers of the synthesis of CRP [24,28,29]. Based on the results, present study observed dietary protease provided anti-inflammatory effects for weaned pigs by attenuating inflammatory immune responses. Further, dietary protease may contribute to reduction of post-weaning stress and mortality by alleviating inflammation of weaned pigs.

\section{CONCLUSION}

The present study showed addition of dietary protease reduced inflammatory immune responses, such as number of WBC and serum TNF- $\alpha$ and TGF- $\beta 1$, of weaned pigs.

\section{REFERENCES}

1. Pettersson D, Pontoppidan K. Soybean meal and the potential for upgrading its feeding value by enzyme supplementation. In: El-Shemy HA, editior. Soybean-bio-active compounds. Rijeka: IntechOpen; 2013. p. 288-307.

2. Qiao S, Li D, Jiang J, Zhou H, Li J, Thacker PA. Effects of moist extruded full-fat soybeans on gut morphology and mucosal cell turnover time of weanling pigs. Asian-Australas J Anim Sci. 2003;16:63-9.

3. Sun P, Li D, Li Z, Dong B, Wang F. Effects of glycinin on IgE-mediated increase of mast cell numbers and histamine release in the small intestine. J Nutr Biochem. 2008;19:627-33.

4. Yoo JS, Jang HD, Cho JH, Lee JH, Kim IH. Effects of fermented soy protein on nitrogen balance and apparent fecal and ileal digestibility in weaned pigs. Asian-Australas J Anim Sci. 2009;22:1167-73.

5. Kong XF, Yin YL, He QH, Yin FG, Liu HJ, Li TJ, et al. Dietary supplementation with Chinese herbal powder enhances ileal digestibilities and serum concentrations of amino acids in young pigs. Amino Acids. 2009;37:573-82.

6. Kang J, Cho J, Jang K, Kim J, Kim S, Mun D, et al. Effects of dietary enzyme cocktail on diarrhea and immune responses of weaned pigs. Korean J Agric Sci. 2017;44:525-30.

7. Bedford MR. Mechanism of action and potential environmental benefits from the use of feed enzymes. Anim Feed Sci Technol. 1995;53:145-55.

8. Liying Z, Li D, Qiao S, Johnson EW, Li B, Thacker PA, et al. Effects of stachyose on performance, diarrhoea incidence and intestinal bacteria in weanling pigs. Arch Anim Nutr. 2003;57:1-10.

9. Kim Y, Baek J, Jang K, Kim J, Kim S, Mun D, et al. Effects of dietary enzyme cocktail on growth performance, intestinal morphology, and nutrient digestibility of weaned pigs. Korean J Agric Sci. 2017;44:513-8.

10. Kim SK, Cho MW, Kim JS, Jang KB, Kim S, Mun DY, et al. Effects of eco-friendly multi-enzyme on growth performance, intestinal morphology, and nutrient digestibility of weaned pigs. Korean J Org Agric. 2018;26:141-9.

11. Min YJ, Kim JS, Kim S, Jang KB, Mun DY, Kim BH, et al. Effects of eco-friendly multi-enzyme on diarrhea and immune response of weaned pigs. Korean J Org Agric. 2018;26:151-61.

12. Glitso V, Pontopidian K, Knap K, Ward N. Development of a feed protease. Ind Biotechnol. 2012;8:172-5. 
13. Stein HH, Sève B, Fuller MF, Moughan PJ, de Lange CFM. Invited review: amino acid bioavailability and digestibility in pig feed ingredients: terminology and application. J Anim Sci. 2007;85:172-80.

14. Cowieson AJ, Lu H, Ajuwon KM, Knap I, Adeola O. Interactive effects of dietary protein source and exogenous protease on growth performance, immune competence and jejunal health of broiler chickens. Anim Prod Sci. 2017;57:252-61.

15. Park S, Lee JJ, Yang BM, Cho JH, Kim S, Kang J, et al. Dietary protease improves growth performance, nutrient digestibility, and intestinal morphology of weaned pigs.J Anim Sci Technol. 2020;62:21-30.

16. Min Y, Choi Y, Kim Y, Jeong Y, Kim D, Kim J, et al. Effects of protease supplementation on growth performance, blood constituents, and carcass characteristics of growing-finishing pigs. J Anim Sci Technol. 2019;61:234-8.

17. Min Y, Choi Y, Choe J, Kim Y, Jeong Y, Kim D, et al. Effects of dietary mixture of protease and probiotics on growth performance, blood constituents, and carcass characteristics of growing-finishing pigs. J Anim Sci Technol. 2019;61:272-7.

18. Choe J, Kim KS, Kim HB, Park S, Kim J, Kim S, et al. Effects of protease on growth performance and carcass characteristics of growing-finishing pigs. S Afr J Anim Sci. 2017;47:697703.

19. Song M, Liu Y, Lee JJ, Che TM, Soares-Almeida JA, Chun JL, et al. Spray-dried plasma attenuates inflammation and improves pregnancy rate of mated female mice. J Anim Sci. 2015;93:298-305.

20. Pluske JR. Invited review: aspects of gastrointestinal tract growth and maturation in the preand postweaning period of pigs.J Anim Sci. 2016;94:399-411.

21. Parkin J, Cohen B. An overview of the immune system. Lancet. 2001;357:1777-89.

22. Seo J, Kim W, Kim J, Kim JK, Kim SC, Jang Y, et al. Effects of palm kernel expellers on growth performance, nutrient digestibility, and blood profiles of weaned pigs. Asian-Australas J Anim Sci. 2015;28:987-92.

23. Qiao S, Li D, Jiang J, Zhou H, Li J, Thacker PA. Effects of moist extruded full-fat soybeans on gut morphology and mucosal cell turnover time of weanling pigs. Asian-Australas J Anim Sci. 2003;16:63-9.

24. Carroll JA, Fangman TJ, Hambach AK, Wiedmeyer CE. The acute phase response in pigs experimentally infected with Escherichia coli and treated with systemic bactericidal antibiotics. Livest Prod Sci. 2004;85:35-44.

25. Nyachoti CM, de Lange CFM, McBride BW, Schulze H. Significance of endogenous gut nitrogen losses in the nutrition of growing pigs: a review. Can J Anim Sci. 1997;77:149-63.

26. Gordon-Smith T. Structure and function of red and white blood cells. Medicine. 2013;41:193-9.

27. Opal SM, DePalo VA. Anti-Inflammatory cytokines. Chest. 2000;117:1162-72.

28. Letterio JJ, Roberts AB. TGF- $\beta$ : a critical modulator of immune cell function. Clin Immunol Immunopathol. 1997;84:244-50.

29. Sanjabi S, Zenewicz LA, Kamanaka M, Flavell RA. Anti-inflammatory and pro-inflammatory roles of TGF- $\beta$, IL-10, and IL-22 in immunity and autoimmunity. Curr Opin Pharmacol. 2009;9:447-53. 